Recent Developments in Iron Age Studies in Northern Rhodesia and Nyasaland

Ancient Ife: an Ethnographical Summary

Some Archaeological Aspects of the Ethnohistory in Uganda

Le Début de l'Age des Métaux dans la région des Grands Lacs africains

L'Archéologie de la région du Tchad

The Nok Terra-cottas in West African Art History
R. Inskeep

W. Fagg and F. Willett

M. Posnansky

J. Hiernaux

J.-P. Lebeuf

B. E. B. Fagg

\title{
Standing Conference on Library Materials on Africa
}

THE Standing Conference on Library Materials on Africa has recently been set up under the Chairmanship of Mr. J. D. Pearson, Librarian of the School of Oriental and African Studies. It was felt that documentary materials for the study of modern Africa in all its aspects were inadequately provided by libraries in the United Kingdom, and the aims of the organization are to facilitate the acquisition and preservation, and to assist in the recording and use, of such materials. Full membership is open to institutions in the United Kingdom actively acquiring library materials on Africa and co-operating in the schemes promoted by the Conference. Supporting membership is open to other bodies interested in the aims of the organization. Representatives of the Colonial Office, the Institute of Commonwealth Studies, London, the Royal Commonwealth Society, Rhodes House, Oxford, the B.B.C., and the London School of Economics, are also on the Committee. The International African Institute was represented on the preliminary working committee. A programme has now been approved and work has already been initiated on some of the projects. The annual subscription is a minimum of $£ 3.3$. All inquiries should be addressed to the Secretary, Miss Dorothy Hamerton, Librarian, The Royal Institute of International Affairs, London, S.W. I.

\section{'Afrique Contemporaine'}

A NEw bi-monthly journal, Afrique Contemporaine, has recently appeared from the Centre d'Études et de Documentation sur l'Afrique et l'Outre-Mer, under the direction of M. Robert Cornevin. The journal contains the text of the most important official documents, a diary of events, analyses of articles in the principal African newspapers, reports of congresses and international organizations, and an annotated bibliography of recent books. It should prove a useful work of reference for politicians, journalists, research workers, and others interested in the development of Africa south of the Sahara. The annual subscription of 16 NF should be sent to L'Administration Abonnements, 16 rue Lord-Byron, Paris 8 e.

\section{Margaret Wrong Memorial Fund: Award for 1961}

The Margaret Wrong Prize and Medal for 196x has been awarded to Mr. S. A. Mpashi, for his very considerable and beneficial influence on the growth of a real interest in reading and writing in Northern Rhodesia, particularly in the Northern, Luapula, and Western Provinces, where Bemba, his own language, is current. Mr. Mpashi joined the Publications Bureau of Northern Rhodesia and Nyasaland in $195 \mathrm{I}$ and is now Senior Bemba Reader/ Translator and the senior of all the reader/translators. He is the author of many books, ranging from novels and short stories to handbooks of advice on manners and morals. 